\title{
RESPONSE TO INTERVENTION FOR STUDENT SUCCESS IN HIGHER EDUCATION: IS IT POSSIBLE?
}

Sylvia Harkins, Grand Canyon University

\begin{abstract}
This study is a literature review to determine what research says about the relationship between Response to Intervention (RtI) and online student success. Response to intervention is a model used to provide students tools and resources to be successful and engaging in the classroom for academic and behavior challenges (Wright, 2007). Online education has become the hottest idea for obtaining a degree in higher education (Wright, 2007). Adult students of all ages, professions and levels of education seek to step into the next level in completing a degree program. Some adult students may not realize the rigor and demands of an online learning environment and find it more challenging than expected. This literature review will examine what research says about RtI, student learning and student success in online higher
\end{abstract} education.

\section{INTRODUCTION}

In the world of education, students are encouraged to stay in school, get a good education and finish college with a degree in order to obtain a good paying job. Some students become inspired to move on from college and begin working on becoming doctors, engineers, teachers, nurses, counselors, chemists, business consultants or another profession of their interest. The first year as a college student is the most critical time of their educational experience (Wright, 2007). It is the first class, the first year in college that will determine whether the student will continue in their education (Brady, 2013). At the university level, there should be interventions, resources, services and tools for students to access for learning, success and retention. The RtI model was developed to identify students' academic and/or behavior difficulties to measure student progress with valid and reliable measures (tiers). Once those difficulties are identified, an RtI model is designed according to the student's needs (Hughes \& Douglas, 2015).

\section{LITERATURE REVIEW}

In this literature review, the following webbased databases were used: EBSCOHost, ProQuest, eBooks with Grand Canyon University Library and the specialized article database of Response to Intervention (RtI) Action Network. Additionally, Web-based search engines served to complement the search. Those search engines were Google.com, Scholar.Google.com, and Ask.com. The types of searches conducted include word, title, subject and author. Examples of terms researched through the Web-based search engines included the following: "RtI in higher education," "response to instruction," "data-based decision making," "intervention-based assessment," "RtI for English Language Learners," "RtI for students with disabilities," and "student learning." Examples of author searchers included the following: Hughes, Dexter, Brown-Chidsey, Bender, Buffum, Fuchs, Mellard, Johnson, Mock, Morgan and Young. This search engine-based research produced sufficient relevant articles at the peer-reviewed and scholarly level. The literature supported a history of study in RtI.

Enrollment for online education has grown in the past eight years and continues to grow in higher education. Allen and Seaman claimed, "Over 6.1 million students were taking at least one online course during the fall 2010 term; an increase of 560,000 students over the number reported the previous year." As enrollment increases, however, completion of degree programs decreases. There 
needs to be an accountability of overcoming challenges for students on "Low persistence, high dropouts, and low completion even as the cost of education has skyrocketed, for students, parents, states and the nation," (Baer \& Duin, 2014, p. 32).

A university should have research-based practices to commit to developing interventions focused on students' learning when transitioning from high school through completion of a degree program (Baer \& Duin, 2014). Response to intervention is a three-tier model that designs a plan of interventions to implement the process of assessments, progress monitoring, teach or reteach (Hughes \& Dester, 2015; Mellard \& Johnson, 2008). These processes will collect data on a student's response to the intervention and what further steps need to be taken to move forward with another intervention for the students. These interventions focus on academics and/or behavioral needs of students (Mellard \& Johnson, 2008).

Response to Intervention model began being implemented in most United States K-12 public school systems as a new way to respond to the instructional needs of their students (Hughes \& Dester, 2015). The RtI model is a promising new process of instruction, assessment and intervention that allows schools to identify struggling students early, provide appropriate instructional interventions, and increase the likelihood that the students can be successful and maintain their class placement (Mellard \& Johnson, 2008). The challenges and needs of students in higher education are clearly different from those in the K-12 setting, yet the principles of RtI can be adapted to assist at this more advanced level of learning. Most online universities do not have a placement test for reading, math and writing. Students are placed in introductory courses. Students who are struggling at the college level in reading, math, and writing should seek or be referred to tutoring services, a mentor, counseling or advisement, hopefully before they decide to drop out of college. There are no remedial courses for reading, math or writing (Grand Canyon University, Walden University, University of Phoenix, Devry University, 2015).

At the college level, there are students who face challenges that become a distraction and/or obstacle for them to be successful in their academics. Those challenges also affect their behaviors as a student or classmate in the universities culture. This also affects student retention which affects students completing a degree program. The RtI program is one avenue that can be implemented at the university level to address academic and behavior difficulties with which students faced. Some of these issues are related to first year of college, family issues, disability, emotions and feelings of disconnection from the university culture, or trying to find a place that he/she fits in the university culture. These are students who will benefit from an RtI program. The RtI model was focused around K-12 environment, but the concept can be adapted and implemented in higher education.

The RtI process promotes an atmosphere of prevention and support through its tiered system, using data to improve courses, programs and procedures, and to support candidates who are struggling to meet content and disposition standards and competencies. It is often explained by the use of a triangle-shaped graphic design. The base of a triangle represents the first tier, the components of which are universal screening, benchmark assessments and tier one interventions and supports that faculty use when students are informally identified as having some difficulty in class. The middle of the triangle represents the point in RtI where students whose needs are not met by Tier 1 strategies are given more intense instruction and appropriate interventions. Tier 3 is at the top of the triangle, where the most intense interventions are administered by resource services provided by the education facility (Wright, 2007).

\section{INTERVENTIONS}

These interventions are research-based practices and instructions for online higher education in the e-learning environment. Some of these research based practices and instructions used in an e-learning environment are Classroom Assessment Techniques (CATs), student learning, student engagement, student services, student retention and differential instruction. These are just a few of the many intervention resources that are out there for students. The list of interventions stated below are the most common interventions that are established in a university.

\section{STUDENT LEARNING - DIFFERENTIAL INSTRUCTIONS}

There are diverse theories and practices on learning styles. Educators are to identify their students' learning style and provide the access 
for students to improve learning. The challenge in online learning is meeting the learning styles of students in an e-learning classroom environment; visual, auditory, logical, social, solitary or kinesthetic. Meeting students' learning needs could be a combination of two or more learning theories or practices. In an online learning environment, there are a variety of technology programs that can be used to meet diverse learning styles. These resources, tools and techniques would include but are not limited to social media (Facebook, Skype), video presentations uploaded into the classroom, teacher-student phone conversations and emails. Learning styles will also dictate the type of resource or tool that should be used to meet students' needs. Along with meeting students' learning styles, strategies and techniques must be included to accommodate the learning style (Brady, 2003). For example, when a student is completing an assignment or taking a test, there should be accommodations for that student.

\section{STUDENT ENGAGEMENT}

Student engagement includes active learning in the e-learning classroom. One area in the classroom that will assess and monitor students' engagement is the discussion forum. Active participation in the discussion forum should include substantive posts related to the topic of the week. Other student engagement may involve other social media when used to create a learning community among students. The challenge for student engagement determines the academic effort they put out in preparing to engage in discussion forums. This will include "...studying, reading, writing, and preparing for class (Robinson \& Hullinger, 2008, p. 103)." Student-faculty interaction plays a role in student engagement, immediate feedback in discussion forums, assignments, grades and participation (Robinson \& Hullinger, 2008). Students' motivation is based on their interest and effort that they engage in their learning. Active learning takes place when students are engaging and collaborating with other students and/or the teacher to make learning effective (Barkley, 2010).

\section{STUDENT SERVICES}

Student services are important outreach to welcome and retain student population, whether online or face-to-face learning. Universities have student services, but how many students are aware or know about those services? Orientation for firstyear college students should include information about these student services. For an online learning environment, informing students about what the university provides both on campus and online gives students a sense of being part of the campus, especially as an online learner. This is where questions and discussions can be included in the e-learning classroom related to student services. This gives students access to explore and discover what the university has to offer and at the same time research their answer to a question that was posted in a discussion forum. Some of the interventions that are provided for student services are tutoring, mentoring, welcome back events, orientation, campus tours, workshops, firstyear seminars and experiences, writing-intensive courses, collaborative assignments and projects, undergraduate research, service learning, meet the faculty night, and other events or activities that will involve collaboration and engagement among students, parents, faculty and staff. This is a way to create a professional learning community that contributes to the success of all students (Baer \& Duin, 2014).

\section{CLASSROOM ASSESSMENT TECHNIQUES}

Tests and quizzes are the be-all and end-all techniques for assessing students' understanding and learning in academics. Assessment can be fun with the right technique to check for understanding. These assessment techniques could be valuating for "...course-related knowledge and skills; analysis and critical thinking; synthesis and creative thinking; problem solving; application and performance; or assessing learner attitudes, values, and self-awareness," (Angelo \& Cross, 1993). In an online higher education learning environment, asking the right question is a strategy to assess students' conceptual awareness and understanding (Dantonio \& Beisenherz, 2001). Asking a question to just ask a question will not be as effective as asking a question that engages students to apply their critical thinking skills from knowledge, comprehension, application, analysis, synthesis and evaluation. Students will need to engage with each other in a discussion that will allow them to share their ideas and learn from each other (Dantonio \& Beisenherz, 2001).

Faculty in higher education should be familiar 
with services that a college or university has available or provides for students who are in need of academic support. The faculty or educator would be the one to ensure the process of the RtI model is started and ended as well as providing documentation of the purpose of the services needed for the student. The data generated by the RtI process for higher education is seen as a valuable tool for program and course review and academic advisors can use this data as one of their tools as well as they seek to find the "best fit" for students from among the many choices that there are for their academic success.

Overall, the RtI model was not created for students with disabilities. Therefore, there are RtI programs that assess and identify students' academic achievement or behavior. The RtI is put into place to measure the student's response or lack thereof to interventions. Once the student's academic or behavior difficulties are identified, an intervention plan with evidence-based and intensive intervention is designed to meet the student's needs. Providing student resources and interventions can make positive changes in academics and behavior. Universities may have student services, clubs and support services. Retaining students involves providing interventions, sharing resources to assist them in making positive changes in their academics and behavior.

\section{Reference}

Baer L. \& Duin, A. H. (2014). Retain your students! The analytics, policies and politics of reinvention strategies. St. Paul, Minnesota. Planning for Higher Education Journal.

Barkley, E. F. (2010). Student engagement technique: A handbook for college faculty. Hoboken, NJ. John Wiley \& Sons, Inc.

Brady, C.L. (2013). Understanding learning styles: providing the optimal learning experience. International Journal of Childbirth Education. Retrieved from https://lopes.idm.oclc. org/login?url=http://search.ebscohost.com/login.aspx?direct=t rue\&db=ccm\&AN=104292450\&site=eds-live\&scope $=$ site

Dantonio, M. \& Beisenherz, P. C. (2001). Learning to question, questioning to learning: developing effective teacher questioning practice. Allyn \& Bacon. Needham Heights, MA.

Devry University. 2015. Academics. Retrieved from http://www. devry.edu/degree-programs.html

Grand Canyon University. 2015. Majors and Programs. Retrieved from http://www.gcu.edu/degree-programs/
Hughes, C. \& Dester, D. D. (2015). Field studies of Rtl Programs, revised. Retrieved from http://www.RtInetwork.org/learn/ research/field-studies-Rtl-programs

Mellard, D.F. \& Johnson, E. (2008). RTI: A practitioner's guide to implementing response to intervention. Thousand Oaks, California. Corwin Press.

Robinson, C. C. \& Hullinger, H. (2008). New benchmarks in higher education: student engagement in online learning. Journal of Education for Business. Retrieved from http:/l eds.a.ebscohost.com.library.gcu.edu:2048/eds/pdfviewer/ pdfviewer?vid=4\&sid=d5cc8a03-2444-44fa-a207-704f4f4251 79\%40sessionmgr4001\&hid=4113

University of Phoenix. 2015. Degree Programs. Retrieved from http://www.phoenix.edu/degrees.html\#

Walden University. 2015. Retrieved from http://info.waldenu.edu/ walden-programs

Wright, J. (2007). RTI Toolkit: A practical guide for schools. Port Chester, NY: Due Publishing.

\section{Author Biography}

Sylvia Harkins is passionate about enlightening educators and practitioners to apply effective and engaging research-based best practices to a variety of learning environments. Her education background is in Public Administration, Reading and Writing, Psychology with an emphasis on Industrial/Organization Psychology, Special Education, and doctoral-level Educational Leadership. She has twenty-plus years of experience in education for reading and writing instruction, curriculum development, classroom management, online education, higher education and leadership. She strives to empower and enlighten others to be successful in their profession and as individuals. 